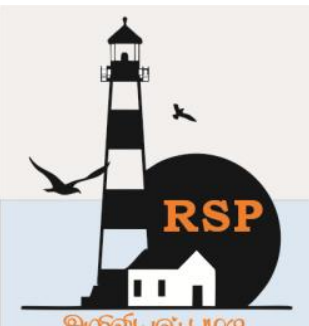

INTERNATIONAL RESEARCH JOURNAL ON ADVANCED SCIENCE HUB

\title{
Promoting the Affective Domain within Global Pandemic: The Challenge of Christian Education
}

Semuel Ruben ${ }^{1}$, Iwan Setiawan ${ }^{2}$, Wilianus Illu ${ }^{3}$, Sri Wahyuni ${ }^{4}$

${ }^{1}$ Lecturer, Dept. of Christian Education, STIPAK Malang, Jl. Janti Barat blok A no 48 Malang, East Java, Indonesia. Email: semuelruben21@gmail.com

${ }^{2}$ Vice-Chancellor for Planning and Development, Indonesian Bible Institute, Jl. Trunojoyo no. 12 Batu, East Java, Indonesia. Email: jenny.iwan08@gmail.com

${ }^{3}$ Head of Department of Missiology, Indonesian Bible Institute, Jl. Trunojoyo no. 12 Batu, East Java, Indonesia.Email: wilianusillu971978@gmail.com

${ }^{4}$ Vice-Chancellor for Ministry, Ebenhaezer School of Theology, Jl. Buluran/Gereja no.2 Tanjung Enim, South Sumatera, Indonesia. Email: yunikusradi@gmail.com

\begin{abstract}
The Christian faith was not merely a matter of knowledge (cognitive domain) alone, but also about feelings and attitudes (affective domain), and deed or practice (psychomotor aspects). All domains in the viewpoint of the Christian faith influenced each other so that all need to get the same judgment. The problem was they were no longer having public meeting, especially in Christian education classes. In the other hand, it was hard to touch affective domain without face-to-face learning. This study investigated the effect of cooperative learning on affective domain in Christian education during the global pandemic of Covid-19. This study was conducted among forty Christian students, and adopted quasi-experimental design with two groups, the experimental group and control group. Prior to the $t$ analysis, the pre-requite test for normality had been conducted. Then, data were analyzed by using paired sample T-Test. The result of analysis revealed that that affective domain in Christian education can be promoted by cooperative learning. Paired sample t-test showed that the value of significance (2tailed) was less than 0.05, indicated that there was a significant difference of mean between pre-test and post-test results. In this regard, cooperative learning can be solution to increase affective domain in Christian education during pandemic. Further studies are suggested to be conducted with larger samples.
\end{abstract}

\section{Keywords: Affective Domain, Global Pandemic, Cooperative Learning, Challenge}

\section{Introduction}

In the perspective of the Christian faith, learning required all three aspects: (a) cognitive aspects; (b) affective aspects; (c) and psychomotor aspects. The Christian faith was not merely a matter of knowledge (cognitive domain) alone, but also about feelings and attitudes (affective domain), and deed or practice (psychomotor aspects) [1]. All domains in the viewpoint of the Christian faith influenced each other so that all need to get the same judgment. The problem was, they were no longer having public meeting, 
especially in Christian education classes. In the other hand, it was hard to touch affective domain without face-to-face learning during Covid-19 pandemic [2]. This study investigated the effect of cooperative learning on affective domain in Christian education during the global pandemic of Covid-19.

\subsection{Implementing Cooperative Learning}

Cooperative learning was a learning model where small groups of people are learning and working in groups of 4-6, which could stimulate learners more passionate about learning. In cooperative learning, the teacher acted as a facilitator that serves as a bridge towards higher understandings, with students' own records [3]. The teacher here played not only to give students knowledge, but to build on their mind as well. Students had the opportunity to gain immediate knowledge in applying their ideas [4]. Cooperative learning was a learning strategy that involved the participation of students in a small group to interact with each other. In the cooperative learning system students learned cooperation with other members. It could be understood that in cooperative learning, students had two responsibilities of learning for themselves, and helping their fellow group members to learn together [5].

The objective of cooperative learning was to create a situation where individual success was determined or influenced by the success of the group, which was then summarized as follows:

- Cooperative learning gave students opportunities for different backgrounds and conditions to work interdependent with one another over tasks together and through the building of cooperative award structures, learning to appreciate each other.

- There were several benefits in cooperative learning for students with low learning achievements including: lower apathy, deeper understanding, increase motivation, higher learning outcomes, longer retention, improves kindness, sensitivity and tolerance.
In addition to enhancing the students' affective skills, cooperative learning also provided other major benefits like the following [6]:

- Students taught with and in cooperative structures would obtain higher learning outcomes;

- Students participating in cooperative learning would have a higher self-esteem attitude and greater motivation for learning;

- With cooperative learning, students became more concerned with their friends, and among them would awaken a sense of positive dependence (positive interdependencies) for their later learning process;

- Cooperative learning increased the sense of acceptance of students to their friends who come from different racial and ethnic backgrounds.

Cooperative skills consisted of 3 forms:

1. Early-level cooperative skills included: a) using the opportunity; b) appreciating contributions; c) taking a turn and share; d) bounding in group; e) focusing on duty; f) encouraging participation; g) stimulating others to speak; h) completing the task in time; i) respecting individual differences

2. Intermediate cooperative skills included: a) showing appreciation and sympathy; b) disclosing disagreement in an acceptable manner; c) active listening; d) asking; e) creating a summary; f) interpreting; g) organizing; h) accepting responsibility; i) Reducing tension

3. Advanced cooperative skills included: a) elaborating; b) checking carefully; c) declaring the truth; d) setting goals; e) compromising

In cooperative learning there were six steps or stages, where learning began with the teacher conveyed learning objectives and motivated students to learn [7]. Further grouped in the learning teams, followed the guidance of teachers at the time students collaborated to complete the task and the last presentation of the group's work [8]. Phases in cooperative learning as below: 
1. Conveying goals and motivate

Teacher conveyed the learning objectives that they want to achieve and motivated students to learn

2. Presenting information

Teacher conveyed information to students by way of demonstrating or through reading materials

3. Organizing students into study groups

Teacher explained students how to form a learning group and help each group to transition efficiently

4. Guiding groups working and learning

Teacher guided learning groups as they perform

5. Evaluating

Teacher evaluated the learning outcomes of the materials that have been studied and each group presented their work

6. Appreciating

Teacher shared how to appreciate each work that had been presented

\subsection{Touching Affective Domain}

Learning outcomes are always associated with achieving goals. Learning outcomes could provide new information about students' achievements in learning and teachers in teaching [9]. The explanation of the learning outcomes based on the points:

A. Cognitive domain

1. Knowledge: memory of things that were special or universal, knowing methods and processes, memory of a pattern, structure or setting;

2. Understanding included acceptance in communication accurately, placing the results of communication in a different form of presentation, organizing it on a level basis without changing the understanding;

3. Application or using principle or method in a new situation;

4. The analysis was concerned primarily with the ability of the child in grouping the material into the parts that formed it, detecting the relationship between the parts and the way the material was organized;

5. The synthesis was one more difficult level;
6. Evaluation was the most difficult part of learners' knowledge ability [10].

B. Attitude (affective) domain

1. Accepting or noticing;

2. Responding was a student engaged or giving participation;

3. Appreciating;

4. Organizing: the form of a value system that can lead to behavior;

5. Implementing the values, meant the values have gained place in the individual.

C. Psychomotor domain

1. Impersonating: a student began to create a clone of the delivered action;

2. Manipulation: displaying an action as taught;

3. Equality: students were able to lead to improvement;

4. Articulation, i.e. students can coordinate the same action by establishing the exact sequence between different actions;

5. Naturalization of children has been able to perform one or several actions.

Based on the exposure described above about the learning outcomes, it could be concluded that the learning results consisted of three things: cognitive, affective, and psychomotor [11]. While in the context of this research focused only on the affective domain (receiving/attending, responding, valuing). Affective domain assessment (attitude) was an assessment conducted by the teacher to measure the achievement level of attitude competency from learners covering the realm of the domain receiving, responding, valuing, and organizing [12].

\section{Method}

This study was conducted among forty Christian students, and adopted quasi-experimental design with two groups, the experimental group and control group. Prior to the $t$ analysis, the prerequite test for normality had been conducted. Then, data were analyzed by using paired sample t-test. Statistical calculation was aided by the SPSS software program. 


\section{Results}

Table.1. Reliability Statistic

\begin{tabular}{|r|r|}
\hline $\begin{array}{c}\text { Cronbach's } \\
\text { Alpha }\end{array}$ & N of ltems \\
\hline .990 & \\
\hline
\end{tabular}

Based on the table 1, Cronbach's Alpha obtained 0.99. It meant that 44 items of the questionnaire were reliabel.

Table 2. Paired Samples Statistics

\begin{tabular}{|rl|r|r|r|r|}
\hline & Mean & N & \multicolumn{1}{|c|}{$\begin{array}{c}\text { Std. } \\
\text { Deviation }\end{array}$} & $\begin{array}{c}\text { Std. Error } \\
\text { Mean }\end{array}$ \\
\hline \multirow{2}{*}{ Pair 1 } & Pre & 71.55 & 20 & 7.082 & 1.584 \\
& Post & 78.50 & 20 & 7.409 & 1.657 \\
\hline
\end{tabular}

In the table above it appeared that the average value for pre-tests was 71.55 . While the average value of post-test was 78.50 .

Table 3. Paired Samples Test

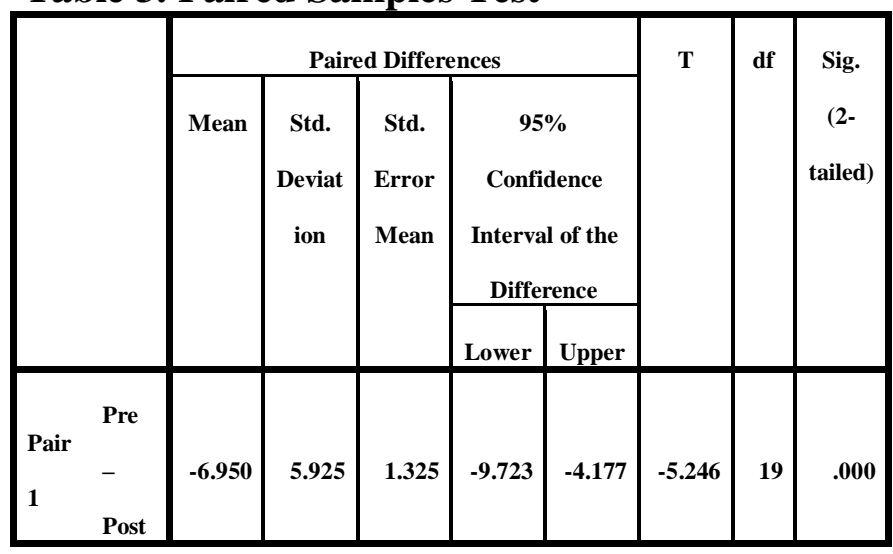

The above table could be noted that the value of Sig. (2-tailed) was $0.000<0.05$. This indicated that there was a significant difference of mean between pre-tests and post-test results, which meant the use of cooperative learning methods for increasing affective domain in Christian education was proven effective.

\section{Discussion}

Affective domain could be explained as bellow: (a) Receiving as a willingness to be aware of a phenomenon in its absence; (b) Responding (response) as giving a reaction to the phenomenon in which it was circled; (c) Valuing (appreciation) with respect to the value applied to an object or phenomenon; (d) Organizing as combining different values, resolving conflicts, and forming a consistent value system [13].

The affective domain as learning outcomes needed to be assessed based on the criteria already written by the teacher. In the assessment of the affective domain, it was very important to see the level of achievement of students' ability [14].

The teachers needed to paid more time in planning and implementation of assessment of students' results through clear judgment principles and procedures that were: (a) in conducting assessment of affective domain must be designed in such a way that clearly the ability to be assessed, assessment materials, assessment tools, and interpretation of assessment results; (b) the assessment of affective domain should be an integral part of the teaching learning process; (c) to obtain objective affective domain in the sense of describing the achievement and ability of the student as it was, the assessment must use various assessment tools and was comprehensive; (d) assessment of affective domain should be followed by follow-up [15].

\section{Conclusions}

The result of the analysis revealed that affective domain in Christian education can be promoted by cooperative learning. Paired sample t-test showed that the value of significance (2-tailed) was less than 0.05 , indicated that there was a significant difference of mean between pre-test and post-test results. In this regard, cooperative learning can be solution to increase affective domain in Christian education during pandemic Covid-19. Further studies are suggested to be conducted with larger samples.

\section{References}

[1] Lawson, K.W. (2020). Taking Educational Ministry with All Ages Seriously. Christian Education Journal: Research on Educational Ministry, 17(1), 3-6. 
[2] Voigt, C. (2010). The Affective Domain and Social Networking. Workshop: $5^{\text {th }}$ ECTEL.

[3] Ariawan, S. (2018). The Effectiveness of Cooperative Learning Method (Student Team Achievement Divisions) in Christian Education. International Journal of Education and Curriculum Application, 1(3), 45-50.

https://doi.org/10.31764/ijeca.v1i3.2128

[4] Ekhuya, M.J. (2019). Christian Religious Education Teachers in Preparation for Teaching on the Affective Domain for Development of Character Education among Learners in Kenya. International Journal of Innovative Research \& Developmen 7(2), 112-119.

[5] Giraud, G. (2017). Cooperative Learning and Statistics Instruction. Journal of Statistics Education, 5(3), 121-130.

[6] Slavin, Robert E. "Cooperative Learning Teori, Riset dan Praktik," Bandung: Nusa Media, (2011).

[7] Ariawan, S. "Kreativitas Mengajar dan Implementasi Konsep Pastor-Teacher," SulSel: CV. Mitra Ilmu, (2020) http://doi.org/10.31237/osf.io/xe95j

[8] Ariawan, S, Kristyana, N. Nurprasetyaningsih, Rusmi. (2020). Virtual Discussion for Improving Motivation: A Christian Education Strategy against Covid-19 Pandemic Effect. International Research Journal on Advanced Science Hub, 2(7), 1-5.

[9] Bergler, T.E. (2020). Generation $\mathrm{Z}$ and Spiritual Maturity. Christian Education Journal: Research on Educational Ministry, 17(1), 75-91.

[10] Ariawan, S. (2019). Countering Zeitgeist of Self-Centered through Role Playing Methods among Junior High School Students. International Journal of Education and Curriculum Application, 2(3), 44-49. https://doi.org/10.31764/ijeca.v2i3.2143

[11] Hoque, M. E. (2016). Three Domains of Learning. The Journal of EFL Education and Research (JEFLER), 2(2), 45-52.
[12] Anderson, L.W., \& Krathwohl, D.R. "A Taxonomy for Learning, Teaching, and Assessing: A Revision of Bloom's Taxonomy of Educational Objectives," New York: Longman, (2000).

[13] Ariawan, S. (2020). Building Critical Thinking in Covid-19 Pandemic Era: Impossible or I am Possible? International Research Journal on Advanced Science Hub, 2(6), 127 130.

[14] Barfield, R. (2019). Children and the Imago Dei: A Reformed Proposal Regarding the Spiritual Openness of the Child. Christian Education Journal: Research on Educational Ministry, 17(1), 7-17.

[15] Ariawan, S. "Etika Guru Pendidikan Agama Kristen," Jawa Tengah: CV. Pena Persada, (2020). 